\title{
Do Ruminants Alter Their Preference for Pasture Species in Response to the Synchronization of Delivery and Release of Nutrients?
}

\author{
J. Hill, ${ }^{1}$ D. F. Chapman, ${ }^{2}$ G. P. Cosgrove, ${ }^{3}$ and A. J. Parsons ${ }^{3}$ \\ Authors are ${ }^{1}$ Senior Lecturer in Animal Nutrition and ${ }^{2}$ Professor of Pasture Science, School of Agriculture and Food Systems, University of Melbourne, \\ Victoria 3010, Australia; and ${ }^{3}$ Senior Scientists, AgResearch Grasslands, Private Bag 11008, Palmerston North, New Zealand.
}

\begin{abstract}
When offered a free choice between different forage species presented in a pasture association, ruminants will choose a mixed diet, even when one dietary component could meet all of their nutritional needs. Thus, preference and selection cannot be explained simply by the common measures of species nutritive or feeding value. The question then arises, what is the nutritional basis of the dietary choices that animals make? The objective of this paper is to review the role of synchronization of forage composition factors and nutrient release patterns on the processes controlling preference in grazing ruminants. The satiety theory is used as a model system to explore outcomes of changing the physico-chemical attributes of forages on grazing behavior of sheep and cattle. The review will examine further the biological basis for the alteration in meal pattern, duration and extent in ruminants offered clover only (relatively high rumen degradable protein content) compared to animals eating only grass (with relatively low rumen degradable protein content), or a mixture of grass and clover. One theory that has been proposed to explain the induction of satiety in grazing ruminants is the rate of release of ammonia from the soluble protein fraction of the forage, and subsequent uptake in the blood. By mixing grass with the clover, the animal is able to increase the duration of the meal potentially reflecting a "better" dietary balance of energy to soluble protein that controls the rate of accumulation of ammonia in rumen fluid. This concept is evaluated in light of recent data from in vitro studies examining digestive efficiency. From this analysis, it is clear that direct, real-time information on the relationships between forage physico-chemical factors, rumen condition, meal initiation and cessation, and dietary switching is needed to further develop propositions about the control of dietary choices of grazing ruminants.
\end{abstract}

\section{Resumen}

Los rumiantes en condiciones de libre pastoreo tienden a escoger una dieta mixta de especies forrajeras de un potrero, aún cuando solo un componente de la dieta pueda suplir todas sus necesidades nutricionales. Así, la preferencia o selección no puede explicarse simplemente por mediciones comunes del valor nutritivo o alimenticio de las especies presentes. De esta manera surge la pregunta, ¿cuál es la base nutricional de la selección de dieta que hace el animal? El objetivo de esta publicación es revisar el papel de la sincronización de los factores de la composición del forraje y el patrón de liberación de nutrientes en los procesos que controlan la preferencia en los rumiantes en pastoreo. La teoría de la saciedad es utilizada como un modelo para explorar los resultados de cambiar los atributos físico-químicos del forraje en el comportamiento de ovinos y bovinos en pastoreo. Esta revisión examinará más allá de las bases biológicas de la alteración del patrón del consumo, la duración, y extensión en los rumiantes a los que se les ofrece solamente trébol (una cantidad relativamente alta de proteína degradable en el rumen) comparado con animales que solamente consumen gramíneas (con un contenido de proteína de relativa baja degradabilidad ruminal), o una mezcla de gramíneas y trébol. Una teoría que ha sido propuesta para explicar la inducción de la saciedad en animales en pastoreo, es la tasa de eliminación de amoniaco desde la fracción soluble de la proteína del forraje, y la sucesiva absorción hacia la sangre. Al mezclar la gramínea con el trébol, el animal es capaz de aumentar la duración de la comida potencialmente reflejando un "mejor" balance dietario de energía a proteína soluble que controla la tasa de acumulación de amoniaco en el fluido ruminal. Este concepto se evalúa a la luz de resultados recientes de estudios de eficiencia digestiva realizados in vitro. A partir de este análisis, está claro que la información directa y en tiempo real sobre las relaciones entre los factores físico-químicos, las condiciones del rumen, el inicio y cese de una comida, y el cambio dietario, es necesaria para desarrollar propuestas más detalladas acerca del control en la selección que hacen los animales en pastoreo.

Key Words: dietary preferences, grazing, nutrients, ruminants, satiety

\section{INTRODUCTION}

The majority of pastures offered to ruminants under intensive production systems are monocultures (for example ryegrass monocultures) that provide a nutrient base that is manipulated by nitrogen and phosphate inputs. Mixtures of grasses and

Correspondence: Julian Hill, School of Agriculture and Food Systems, University of Melbourne, Victoria 3010, Australia. Email: julianh@unimelb.edu.au

Manuscript received 26 March 2008; manuscript accepted 3 April 2009. legumes also are used commonly in pastures because legumes fix atmospheric nitrogen, some of which is eventually transferred to the associated grasses, thereby reducing fertilizer input costs. Legumes also provide forage of consistently high digestibility and protein content, whereas grasses display marked seasonal variation in feeding value. In general, these pastures do not provide either 1) adequate year-round supply of feed or 2) an adequate nutritive composition to support high levels of animal production (Doyle et al. 2000), and normally, supplementation using a range of forages and concentrates is 
necessary to ensure adequate supply of nutrients for highproducing animals such as dairy cows. Recent research in Europe, Australia, and New Zealand (reviewed by Rutter 2006; Chapman et al. 2007a) has examined the idea of allowing the grazing animal to express free dietary choice between legumes and grasses during grazing as a means toward achieving greater consistency of nutrient supply to the animal from pasture, and greater control of intake and production.

When offered a free choice between different forage species presented in a pasture association, ruminants choose a mixed diet, even when one dietary component could fulfil the nutrient requirements of the animal (Dumont 1997). The processes that underpin the animals' ability to express choice when grazing are poorly understood. Recent reviews by Rutter (2006), Chapman et al. (2007a), and Provenza et al. (2007) have focused on the various theories that account for ruminants eating mixed diets. These reviews have examined the tradeoffs between nutrient intake and animal requirement, maintenance of rumen function, and avoidance of toxins, to assess the impact of multiple tradeoff scenarios that occur when the animal attempts to achieve its goals during grazing. This review focuses on the role of synchronization of forage composition factors and nutrient release patterns on the processes controlling preference and selection in grazing ruminants. We attempt to evaluate the biological basis for the alteration in meal pattern, duration, and extent in ruminants offered grass-legume mixtures using data from experiments with sheep and dairy cows.

One theory that has been proposed to induce satiety in grazing ruminants is the rate of release of ammonia from the soluble protein fraction of the forage, and subsequent uptake in the blood (Conrad et al. 1977; Kertz et al. 1982; Villalba and Provenza 1997). By mixing grass with the clover, the animal seems to be able to increase the duration of the meal, potentially reflecting a "better" dietary balance of energy to soluble protein that controls the rate of accumulation of ammonia in rumen fluid (Parsons et al. 1994).

The review will introduce the concepts of preference, selection, and free choice as commonly understood in ruminant nutrition. These concepts will be examined in the light of pasture systems based on monocultures, mixtures, or spatially separated swards composed of perennial ryegrass and clover (white or subterranean). Observations concerning the performance of animals managed under grazing systems that allow partial preference and free choice are evaluated against more recent data based on detailed laboratory and feeding studies designed to examine synchronization theory and rumen function. The evaluation of these data sets leads to the proposition that the cessation of feeding bouts of ruminants grazing pasture systems that allow partial preference is based on the rate of release of ammonia and changes in the balance of glucogenic to nonglucogenic volatile fatty acid (VFA) production.

\section{PREFERENCE, SELECTION, AND FREE CHOICE}

During the annual production cycle, the grazing ruminant faces a number of extremes in metabolism: for instance, the extremes in energy requirement during early lactation, the concomitant control of lactation persistency, the reduction in voluntary intake during late pregnancy, and the challenges of tissue mobilization and accretion (long-term control of body condition). It therefore is not surprising that the voluntary intake of energy over the whole production cycle correlates with energy output (milk production, offspring, etc.) and that, in the majority of cases, the grazing animal has a marginal nutrient status (Knight 2001; Allen et al. 2005). A good example of this is if environmental conditions allow, ruminants will exhibit hypophagia by altering their pattern and duration of meals even when the body energy reserves appear to be replete to anticipate future energy needs (Baile and McLaughlin 1987; Ketelaars and Tolkamp 1992a, 1992b; Speakman et al. 2002).

In this paper we use the following definitions for preference, selection, and free choice: preference is what an animal chooses to eat in the absence of any physical restriction of access to any of the components on offer (Parsons et al. 1994); selection is the preference of the animal modified by physical constraints to access to at least some of the components on offer (Hodgson and Brookes 1999); and free choice is a management construct designed to allow animals to express preference. These phenomena can be interpreted in different ways according to the species of animal being studied, but in the context of ruminant research, they reflect the current opinions of the discipline. Preference, selection, and the ability to exercise free choice when grazing all influence the type and rate of acquisition of nutrients from the pasture resource. The theoretical framework that underpins dietary preference, selection, and free choice in ruminants is informed by several hypotheses. These include 1) selection, choice, and preference are constrained by the animals' capacity to detoxify plant secondary compounds or products of digestion that are potential "toxins;" 2) satiety can reflect a decreased preference for the food just eaten; 3) eating a range of food types can reduce an animal's reliance on any one, thus increasing the range of pasture resources available; 4) modifications in ingestive behavior reflect "tradeoffs" between energy expenditure to forage and nutrient acquired during foraging; and 5) ingesting mixed diets leads to the animal regulating its intake of nutrients by balancing the intake of complementary foods (nutrient synchronization).

\section{The Tradeoff Between Quantity and Quality}

It is well established that there are differences between the intake potential of the grazing ruminant and the actual intake of pasture achieved under current production systems (Ketelaars and Tolkamp 1992a, 1992b; Yearsley et al. 2001). The factors that lead to these differences are categorized into pasture management factors and animal factors, the former being reviewed in some detail by Doyle et al. (2000). Hodgson and Brookes (1999) defined the underlying biological processes that control voluntary intake of ruminants at pasture as 1) the "feeding drive" of the animal (genotype) governed by postabsorptive requirements for nutrients, and consequence of supply, to support animal performance; 2) "physical satiety" associated with physical digestive processes in the gastrointestinal tract, and 3) "behavioral constraints" arising from the interaction among pasture, supplement, and animal. These three factors are not mutually exclusive or additive and the interactions between them drive the processes of voluntary intake (Mayne and Wright 1988). 


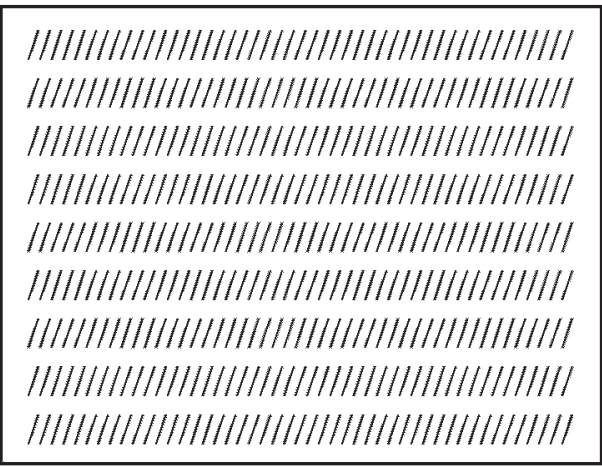

c)

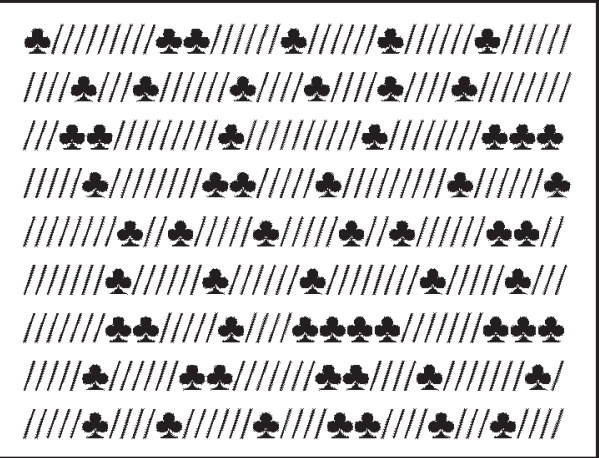

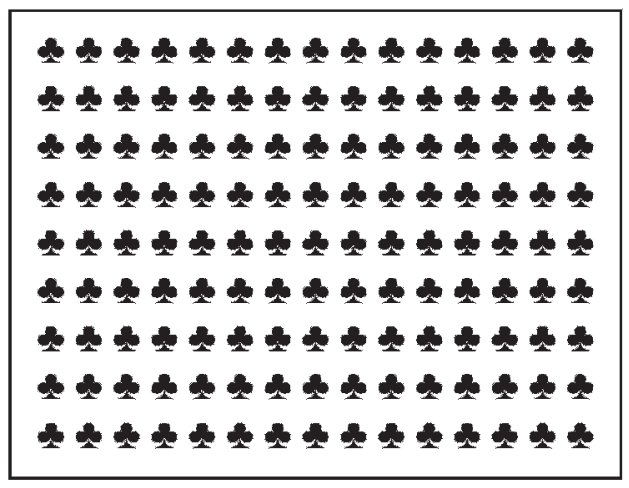

d)

Figure 1. A conceptual diagrammatic representation of the model experimental system used to compare animal grazing behavior and intake on different pasture treatments: a, grass monoculture; $\mathbf{b}$, clover monoculture; c, intermingled grass and clover; and $\mathbf{d}$, adjacent grass and clover monocultures (50:50 area ratio). The squares simply represent the grazing area offered to animals. Treatments $\mathbf{a}$ and $\mathbf{b}$ allow no dietary choice. Treatments $\mathbf{c}$ and $\mathbf{d}$ allow choice, but in $\mathbf{c}$ the choice is constrained because the clover fraction of total dry matter on offer is commonly around 0.2. In d, the choice is not constrained because animals can move freely between the grass and clover monocultures, and there is usually sufficient feed available on each monoculture to meet total animal demand should they exhibit absolute preference for just one component of the choice.

The processes controlling voluntary intake of ruminants grazing on free-choice pasture associations are poorly understood and can be examined as a series of tradeoffs rather than individual processes that can be adapted. The framework to understand the apparent tradeoffs observed in grazing ruminants includes the satiety theory of Provenza (1995, 1996), Fryxell's (1991) theory of forage maturation, and the constraints of foraging behavior in short and long time frames (Forbes 1995). The satiety theory (Provenza 1995, 1996) proposes that grazing ruminants managed under free-choice pasture systems will select a mixed diet even when one food alone will fulfill their nutritional needs, and when toxins are absent. Furthermore, this theory also must be considered in light of the forage maturation hypothesis of Fryxell (1991), which suggests the grazing ruminant faces a tradeoff between food items that ensure an adequate quantity and those that supply adequate quality.

To determine the role of preference and selection in ruminant production systems, two questions first must be addressed. First, what is the partial preference for legume in a mixed diet? And second, do ruminants grazing spatially separated grass and clover pasture associations, where they can express preference, achieve a higher level of production than those grazing conventional mixed swards where they must rely on selection to manipulate their diet?

\section{Partial Preference}

To address the first question, the model system shown in Figure 1 comparing animal grazing behavior and intake on grass monocultures (typically perennial ryegrass, Lolium perenne L.), clover monocultures (typically either white clover, Trifolium repens L., or subterranean clover, Trifolium subterraneum L.), intermingled grass and clover, or adjacent (spatially separated) monocultures of grass and clover has been used widely (see for example Rutter 2006). When offered a free choice between adjacent monocultures of grass and clover, the partial preference of sheep and cattle for clover in a mixed pasture association of grass and clover is about $70 \%$ (Rutter 2006; Chapman et al. 2007a). This is relatively consistent (partial preference for clover $70 \pm 10 \%$ for 18 studies) across studies conducted in northern Europe, continental United States, Australia, and New Zealand with sheep and cattle (Chapman et al. 2007a). Furthermore, Rutter (2006) demonstrated that partial preference differed between animals of 
different physiological states (lactating vs. nonlactating). The partial preference for white clover by lactating ruminants was estimated as $75 \pm 5 \%$ compared to $65 \pm 5 \%$ for nonlactating ruminants. The consistency of these results suggests that randomness and indifference can be discounted, and that animals actively seek a diet that contains a predominance of clover. Furthermore, these studies also have considered the possibility that the animals are responding to novelty, have poor spatial memory, or are avoiding toxins or the consequences of excess consumption of one component of the sward. As yet there are few data on the maintenance of diversity of rumen microflora, the role of carbon/nitrogen $(\mathrm{C} / \mathrm{N})$ ratio of the diet, or the potential influence of synchronization (or a lack of) in rumen function on preference for clover in animals grazing mixed swards.

\section{Animal Performance}

In the course of investigating behavioral responses to the various treatments in the model experimental system shown in Figure 1, several authors also have measured animal production responses to the same four treatments. In the majority of studies examining live weight change in suckling and weaned lambs, allocation to adjacent monocultures of grass and clover led to increases in animal production compared to the conventional intermingled grass-clover association. For example, Chapman et al. (2007a) compiled data from a range of studies conducted with growing lambs that demonstrated an advantage to the free choice treatment compared to the intermingled grass-clover association of $+88 \mathrm{~g}$ live weight gain $\cdot \mathrm{head}^{-1} \cdot \mathrm{d}^{-1}$. Furthermore, mean differences of $+96 \mathrm{~g}$ live weight gain $\cdot$ head ${ }^{-1} \cdot \mathrm{d}^{-1}$ in contrasts between free choice grass-clover vs. grass monocultures and $+3 \mathrm{~g} \cdot$ head $^{-1} \cdot \mathrm{d}^{-1}$ in contrasts between free choice grass-clover vs. clover monocultures were observed.

There is less information concerning the impact of maximizing free choice and preference on the performance of dairy cows. Marotti (2004) observed $+4.6 \mathrm{~kg}$ more milk $\cdot \mathrm{head}^{-1}$. $\mathrm{d}^{-1}(+24 \%)$ when dairy cows in midlactation grazed adjacent monocultures of ryegrass and white clover compared to a ryegrass monoculture. However, the difference between mixed grass-clover and spatially separated monocultures of ryegrass and white clover was smaller $(+1.9 \mathrm{~kg}$ milk yield. head $^{-1} \cdot \mathrm{d}^{-1}[+7.5 \%]$ in favor of the spatially separated swards). There is also evidence that the biological response to spatially separated swards compared to mixed swards is different in early lactation. Rutter et al. (2003) observed an increase in milk production of $+14.7 \%$ in early lactation cows offered spatially separated swards compared to those grazing mixed swards. This poses an interesting question-does the animal's motivation to eat (to acquire energy from the pasture resource) enhance the expression of preference?

If the animal is allowed to express partial preference under a spatially separated pasture system, the importance of the Provenza's satiety theory is paramount. In the previous section, we assumed the monoculture provides an array of nutrients that are adequate to provide for the nutritional needs of the animal and any postingestive feedback resulting from excess supply of rumen degradable protein is minimal, a scenario that assumes synchronization of release of feed nitrogen $(\mathrm{N})$ and organic matter $(\mathrm{OM})$ truly digested in the rumen. In practice, this situation is not likely to occur, even under the best pasture management systems, because the supply of soluble protein from grazed grass is always in excess of the supply of fermentable metabolizable energy (FME) and hence the effective rumen degradable protein (eRDP) requirements of the animal. The postingestive consequences of grazing pastures include elevated concentrations of ammonia in rumen fluid and circulatory blood, a toxin burden to the animal insofar as the ammonia needs to be either assimilated into amino acids or removed via urinary excretion. This proposition is supported by the work of Penning et al. (1991) and Marotti (2004). In both experiments, conducted with lactating dairy cows grazing ryegrass monocultures, clover monocultures, or choice treatments, cows offered clover only or the choice treatment took more frequent, shorter meals, compared with cows offered ryegrass only. The conclusion from these studies was that animals offered clover or the choice treatment forego (potential) voluntary intake reflecting a cue or constraint that led to cessation of grazing before physical satiety occurred. These observations do not support the initial premise that nutritional (energy output) demand stimulates the animal to graze, i.e., to acquire more energy to meet the long-term nutritional needs of lactation or growth. Furthermore, the changes in ingestive behavior (more frequent and shorter meals) are reminiscent of animals offered foods containing plant secondary products. At critical thresholds, plant secondary products satiate the detoxification processes at either the rumen or postabsorptive levels leading to a cessation in feeding. Only when toxin concentrations reduce (normally in the blood) to levels that can be processed through the normal detoxification systems and eliminated, does the animal resume eating (Pfister et al. 1997). We propose that partial preference and selection observed in cows and sheep grazing spatially separated swards is the consequence of the formation of a "toxin" from a nutrient rather than ingestion of a plant secondary compound, and that the "toxin" satiates the detoxification processes leading to the cessation of eating.

\section{DIGESTIVE EFFICIENCY, SYNCHRONIZATION, AND SATEITY}

The results of Cosgrove et al. (2002) and Marotti (2004) lead to the proposition that animals managed under grazing systems that offer the opportunity of free choice exhibit selection on the basis of protein intake as well as energy maximization. These studies are supported by experiments evaluating the responses of dairy cows to a choice-selection for level of feed protein (metabolizable protein [MP] to metabolizable energy [ME] ratio of 6 or $9 \mathrm{~g} \cdot \mathrm{MJ}^{-1}$ ) and the quality of feed protein, i.e., the variation in quickly degradable protein (QDP), eRDP to FME rather than MP to FME ratio (Tolkamp et al. 1998a). The key observation in the housed feeding studies of Tolkamp et al. (1998b) was that an additional dietary supply of QDP (urea) in the ration led to a shift in preference from high eRDP to low eRDP diets, whereas the withdrawal of QDP from diet led to a change in preference to high eRDP rations. Furthermore, the change in the acceptability of the supply of eRDP was observed when no change in voluntary feed intake was observed after the addition of urea. This would suggest that the basis of the change in dietary choice was a feedback mechanism driven by 
rumen functionality rather than a postabsorptive energy-driven mechanism controlling the clearance of ammonia via the urinary pathway. If the latter was predicted, then the animal would attempt to increase its intake of energy by consuming more feed, as is frequently observed with animals offered rations containing high concentrations of urea or other sources of QDP. In practice, the converse is observed. Ruminants managed under housed conditions do not change their intake of energy (Tolkamp et al. 1998b) and, when at pasture and offered a choice between clover and grass, animals reduce their intake of feeds that seemingly supply excess QDP and eRDP but do not compensate for the reduction in intake by eating more grass.

Currently, there is not enough information from housed or grazing studies to provide unified theory/theories to explain the tradeoffs and consequent changes in behavior and preference. It is, however, worthwhile to explore two possibilities, although they are interlinked to a certain extent: 1) the theory of synchronization and 2) the possible role of $\mathrm{C} / \mathrm{N}$ balance of feeds and its impact on rumen functionality. Calculations of the yield of microbial protein are based on the amount, type, and availability of organic matter (the principle of rumen fermentable organic matter and hence FME), and the supply and quality of protein (Egan 1977; Leng 1990; Standing Committee on Agriculture 1990). These calculations result in a nondynamic estimate of microbial protein yield, and do not reflect the influence of nutrient supply on microbial metabolism (Baldwin et al. 1987; Lescoat and Sauvent 1995). This might explain why there seems to be a lack of response in rate of synthesis or yield of microbial protein when animals are offered a range of diets with different calculated synchrony indices (Kaswari et al. 2007; Table 1). In theory, synchronization should play an important role in the discussion of partial preference of grazing ruminants. However, the problems associated with the measurement of feed intake at pasture, substantial variability in grazing behavior in relation to changes in sward composition, and structure and the lack of dynamic models to predict nutrient release and conversion to microbial protein (Dijkstra et al. 1993, 2002) lead to substantial problems in the interpretation of experiments examining the theories associated with synchrony of nutrient release over short (hourly) and long (daily) time frames (Newbold and Rust 1992). Furthermore, there is a lack of consensus over the dietary conditions that lead to synchronization and an increase in microbial protein yield (Sinclair et al. 1993, 1995; Kolver et al. 1998; Shabi et al. 1998; Kim et al. 1999; Richardson et al. 2003; Kaswari et al. 2007). The problem with the majority of studies is that they have been undertaken by exchanging feed ingredients, an approach that confounds the effects of synchronization with the effects of the individual feedstuffs (Dewhurst et al. 2000), rather than manipulating the release of energy and nitrogen by feeding the same energy and $\mathrm{N}$ yielding feeds in different sequences (Kaswari et al. 2007).

Recently, Chapman et al. (2007b) presented an analysis of in vitro studies evaluating the potential of the $\mathrm{C} / \mathrm{N}$ balance and synchronization theory to explain dietary choices. In a series of experiments, sheep were acclimatized to a range of pasture diets containing different area ratios of subterranean clover and perennial ryegrass. Rumen samples taken from the different dietary treatments were incubated with different ratios of ryegrass and subterranean clover substrate to determine if the rumen microflora can readily adapt to changes in feedstuff and
Table 1. The relationship between synchronization index ${ }^{1}$ and efficiency of microbial nitrogen (N) synthesis (reproduced from Kaswari et al. 2007).

\begin{tabular}{cccc}
\hline Source & Method, animal & Synchronization index ${ }^{2}$ & $\begin{array}{c}\text { Efficiency of } \\
\text { microbial N } \\
\text { synthesis }\end{array}$ \\
\hline Blümmel et al. & In vitro & 0.78 & $26.3^{3}$ \\
2001 & & 0.78 & 28.0 \\
& & 0.79 & 28.0 \\
& & 0.82 & 28.8 \\
Sinclair et al. & In vivo, sheep & 0.83 & 30.5 \\
1993 & & 0.58 & $27.0^{4}$ \\
Sinclair et al. & In vivo, sheep & 0.63 & 30.8 \\
1995 & & 0.93 & $27.5^{3}$ \\
Kaswari et al. & In vivo, dairy cows & 0.52 (FS-B) & 30.7 \\
2007 & & 0.76 (FS-A) first & $31.1^{5}$ \\
& & experiment & 26.1 \\
& & 0.82 (FS-C) & 30.1 \\
& In vivo, dairy cows & 0.72 (FS-C) & $31.5^{5}$ \\
& & 0.85 (FS-A) second & 29.9 \\
& & experiment & \\
& & 0.90 (FS-B) & 39.2 \\
\hline
\end{tabular}

${ }^{1}$ Synchronization index $=\left[25-\Sigma_{1-n} /(25-\right.$ release of N/OM perzh $\left.) / n\right] / 25$, where $25 \mathrm{~g}$ $\mathrm{N} \cdot \mathrm{kg}^{-1}$ organic matter (OM) truly digested in the rumen was assumed as the optimal ratio for maximum efficiency of microbial protein production (Sinclair et al. 1993); $n=$ number of intervals that $\mathrm{OM}$ and crude protein degradation was calculated, and $\mathrm{z}=$ release of N/OM per unit time, viz. if six 4-h intervals are used to calculate the release rate of $\mathrm{N}$ and $\mathrm{OM}$, then $n=6$ and $\mathrm{z}=4$.

${ }^{2}$ The details of the rations identified as FS-A, FS-B, and FS-C can be found in Kaswari et al. 2007.

${ }^{3} \mathrm{~g}$ microbial $\mathrm{N} \cdot \mathrm{kg}^{-1}$ fermentable organic matter (FOM), calculated on the assumption that $1 \mathrm{~kg}$ microbial biomass contained $84.7 \mathrm{~g} \mathrm{~N}$.

${ }^{4} \mathrm{~g}$ microbial $\mathrm{N} \cdot \mathrm{kg}^{-1} \mathrm{OM}_{\text {truly digested }}$ in the rumen based on $\left[{ }^{3} \mathrm{H}\right]$ leucine.

${ }^{5} \mathrm{~g}$ microbial $\mathrm{N} \cdot \mathrm{kg}^{-1}$ FOM.

the consequences of change in nutrient supply on gas production, VFA, and ammonia yield. The treatments that demonstrated the greatest total gas production and VFA yield were those that contained 0.67 subterranean clover and 0.33 ryegrass, and 0.84 subterranean clover and 0.16 ryegrass (Table 2). Furthermore, these treatments also demonstrated the greatest resilience to change when challenged with either $100 \%$ subterranean clover or $100 \%$ perennial ryegrass substrate (data not presented). These observations assist the development of an understanding of the potential role of synchrony and $\mathrm{C} / \mathrm{N}$ balance in the processes that control cessation of grazing in ruminants offered free choice in the grazing system. The grazing animal faces two apparent challenges when it attempts to control the processes of fermentation by altering the dietary inputs: the clearance of the "toxin" ammonia and the role of hypophagia resulting from the supply of the glucogenic VFA propionate.

The processes involved with the clearance of excess ammonia are the supply of energy yielding substrates at a rumen level; the formation of glucogenic VFA; and the transport to, and utilization of, energy yielding substrates by tissues. Data from Marotti (2004) demonstrate the ratio of yield of ammonia to propionate (corrected for voluntary intake) liberated during fermentation of diets to be substantially higher in treatments offering clover only (8.1:1) compared to those offering mixed herbage $(2.8: 1)$. Furthermore, if the mixed diets were offered as 
Table 2. In vitro gas production dynamics generated by rumen fluid from sheep acclimatized to background dietary treatments of pure perennial ryegrass $(1.0 \mathrm{RG})$, pure subterranean clover $(1.0 \mathrm{C})$, or adjacent monocultures of clover $(\mathrm{C})$ and ryegrass (RG) in different proportions (surfacearea basis).

\begin{tabular}{|c|c|c|c|c|c|c|}
\hline \multirow[b]{2}{*}{ Treatment } & \multicolumn{6}{|c|}{ Variable } \\
\hline & $\mathrm{Y} \times \mathrm{S}_{0}(\mathrm{~mL})^{1}$ & $b^{2}$ & $c^{2}$ & $T(h)$ & $\mathrm{U}_{0}\left(\mathrm{~g} \cdot 100 \mathrm{~g}^{-1}\right)^{3}$ & $E(\%)^{4}$ \\
\hline $1.0 R G$ & 287.4 & 0.0461 & 0.0032 & 2.1 & 20.9 & 43.7 \\
\hline 0.33:0.67 C:RG & 306.1 & 0.0467 & 0.0033 & 1.7 & 20.6 & 45.4 \\
\hline 0.67:0.33 C:RG & 330.6 & 0.0471 & 0.0035 & 1.4 & 18.7 & 47.3 \\
\hline 0.84:0.16 C:RG & 346.7 & 0.0480 & 0.0036 & 1.6 & 17.6 & 47.7 \\
\hline $1.0 \mathrm{C}$ & 317.9 & 0.0471 & 0.0034 & 1.3 & 19.4 & 46.0 \\
\hline $\operatorname{Sed}^{5}$ & 18.1 & 0.0122 & 0.0008 & 0.7 & 2.1 & 3.4 \\
\hline
\end{tabular}

${ }^{1} \mathrm{Y} \times \mathrm{S}_{0}=$ maximum gas produced.

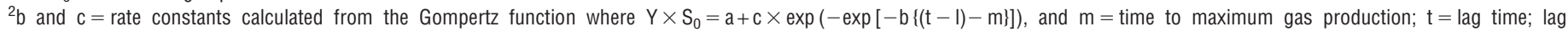
$(\mathrm{I})=\mathrm{m}-\ln (-\ln [-\mathrm{a} / \mathrm{c}]) / \mathrm{c}$.

${ }^{3} U_{0}=$ undegraded fraction.

${ }^{4} \mathrm{E}=$ effective degradability at $0.03 \cdot \mathrm{h}^{-1}$ outflow.

${ }^{5}$ sed $=$ standard error of difference $(4,19 \mathrm{df})$.

clover first followed by grass, or grass followed by clover, there was a difference in the ratio of ammonia to propionate $(4.88: 1$ vs. 3.45:1, respectively; Table 3). These data suggest an asynchrony in the supply of carbon $(\mathrm{C})$ and $\mathrm{N}$ in the diet. Of further interest is the time to maximum concentration of ammonia and propionate (Table 4). The time to maximum concentration of ammonia for the monocultures ranged from $117 \mathrm{~min}$ to $158 \mathrm{~min}$ for clover only and grass only, respectively. However, when a mixed herbage ration was offered, time to maximum concentration of ammonia did not vary significantly from the grass-only treatment (170 min vs. $159 \mathrm{~min}$ for clovergrass and grass-clover sequences, respectively). Propionate synthesis was substantially greater in the clover-only treatment compared with grass-only, a situation that can lead to hypophagia, especially in light of the observation that the total VFA yield of animals adapted to white clover only was comparable to animals offered ryegrass only and substantially less than animals on mixed herbage rations. This is demonstrated by the calculation of the nonglucogenic to glucogenic VFA ratio (NGR; Fig. 2).

Recent studies by Venning et al. (partially reported in Chapman et al. 2007a, 2007b), investigating the ability of the rumen microflora to adapt and change function when challenged with a novel feed, provide an important piece of evidence to support the "ammonia-toxin" theory as well as information on the impact of VFA synthesis on voluntary feed intake. The proposition that ammonia plays an important role in the regulation of feed intake of grazing ruminants is attractive; however, the data of Marotti (2004) and Chapman et al. (2007a, 2007b) also highlight a key role of glucogenic and nonglucogenic VFA. If rumen fluid collected from animals acclimatized to ryegrass-only diets is "challenged" with cloveronly, the rate of change in the ratio of nonglucogenic to glucogenic VFA (NGR) is more rapid during the first $4 \mathrm{~h}$ of fermentation than that observed when the same rumen fluid is challenged with ryegrass only, i.e., the same diet to which the animals were adapted initially (Fig. 3). However, in the case of animals acclimatized to rations containing 0.67 clover: 0.33 grass, the rate of change in NGR is lower than the ryegrass-only treatment when challenged with grass-only. These data suggest the rumen microflora has a greater resilience to challenge and that the production of C3 VFA is more sustained when animals consume a mixed diet, potentially leading to a lower impact on the oxidation-gluconeogenesis ratio and thus a reduced likelihood of cessation of feeding (Allen et al. 2005; Fig. 4).

The type and composition of VFA formed depends on the composition of the microbial population (Dijkstra et al. 2002), the substrate fermented (Bermingham et al. 2007), the balance of nutrients supplied because of the pattern of ingestion (Illius and Jessop 1996), the environmental conditions in the rumen, and the characteristics of microbial metabolism (Bannink et al. 2006, 2007). However, all these factors are closely interrelated. Inevitably, the clearance of VFA and lactate from the rumen and the subsequent postabsorptive effects of those energyyielding substrates are important in understanding voluntary feed intake of animal grazing monocultures or spatially separated pasture systems (Dijkstra et al. 1993). The factors that affect the clearance rate of VFA are $\mathrm{pH}$, lipophylicity

Table 3. Mean and maximum ratio of rumen ammonia:propionate concentration over an 8-h period postfeeding in housed sheep adjusted for intake of crude protein (CP) and dry matter (DM), respectively ( $\mathrm{mM} \cdot \mathrm{kg}^{-1} \mathrm{CP}$ intake; $\mathrm{mM} \cdot \mathrm{kg}^{-1} \mathrm{DM}$ intake), of a range of rations containing pure perennial ryegrass $(R G)$, pure white clover $(C)$, or mixtures of ryegrass and white clover (sequence of offer of $R G$ then $C$, or $C$ then $R G$ ). Ratios were measured immediately before feeding and $8 \mathrm{~h}$ postprandial are also presented. After Marotti (2004).

\begin{tabular}{lcccc}
\hline Treatment & Mean $\left(\mathrm{CV}_{\mathrm{R}}\right)^{1}$ & Maximum & Before & $8 \mathrm{~h}$ postprandial \\
\hline RG & $2.44(0.130)$ & $2.84(0.106)$ & $2.60(0.098)$ & $2.30(0.097)$ \\
$\mathrm{C}$ & $7.22(0.282)$ & $8.08(0.166)$ & $7.64(0.120)$ & $2.28(0.142)$ \\
RG/C & $2.81(0.139)$ & $3.45(0.111)$ & $3.13(0.099)$ & $2.71(0.102)$ \\
C/RG & $4.06(0.224)$ & $4.88(0.125)$ & $4.54(0.104)$ & $3.41(0.103)$ \\
\hline
\end{tabular}

${ }^{1} \mathrm{CV}_{\mathrm{R}}$ (coefficient of variation of ratio) reported in parenthesis. 
Table 4. Time (minutes) to maximum concentration of ammonia and propionate in the rumen of housed sheep offered rations containing pure perennial ryegrass $(R G)$, pure white clover $(C)$, or mixtures of ryegrass and white clover (sequence of offer of $R G$ then $C$, or $C$ then $R G$ ). After Marotti (2004).

\begin{tabular}{lll}
\hline Treatment & Ammonia & Propionate \\
\hline $\mathrm{RG}$ & 158 & 197 \\
$\mathrm{C}$ & 117 & 145 \\
$\mathrm{RG} / \mathrm{C}$ & 159 & 203 \\
$\mathrm{C} / \mathrm{RG}$ & 170 & 212 \\
sed & $20.9^{P<0.05}$ & $34.2^{P>0.1}$ \\
\hline
\end{tabular}

${ }^{1}$ sed $=$ standard error of difference $(3,19 \mathrm{df})$.

(Balaz 2000), rumen volume, epithelial mass (Enemark et al. 2002; Bannink et al. 2007) and metabolic rate, and fluid outflow rate (Chilibroste et al. 2001; Lopez et al. 2003).

Changes in feeding strategy and ration formulation alter the production of VFA (and ammonia), and intraepithelial VFA metabolism. These changes in VFA production in the rumen are not closely reflected in net appearance in portal blood. However, the proportion of individual VFA in the portal blood differs in comparison to the net production in the rumen. This difference reflects epithelial and transport processes and the potential interconversion of VFA through epithelial metabolism (Kristensen and Harmon 2004). In general, the proportions of acetate, propionate, and butyrate are greater, lesser, and lesser, respectively, in portal blood compared to rumen fluid. As the intraruminal load of VFA increases, the proportion of VFA metabolized during transport declines, reflecting saturation of CoA-synthetase (Scaife and Tichivangana 1980; Bannink et al. 2006). The adaptive nature of the rumen epithelia to the amounts of VFA supplied is important in the transport of propionate, the precursor of glucose in metabolism.

One of the important theories that might explain cessation of feeding and switching of diet is the hypophagic effect of propionate and, potentially, ammonia, yielded to portal circulation (Allen et al. 2005). It has been demonstrated that propionate linearly decreases intake of ME compared with acetate, an observation that is explained by increasing concentrations of propionate increasing satiety and possibly decreasing hunger. The difference between the response in intake to acetate or propionate is not purely a response to the additional energy supplied by the VFA, and demonstrates that ruminants do not consume feed to meet their energy requirements per se but they have a fuel-specific mechanism for feed intake regulation (Allen et al. 2005). In the case of ammonia, it is suggested that increased supply to portal circulation leads to a change in the balance between gluconeogenesis and oxidation by altering the bicarbonate and glutamine loadings, thus leading to a "hypophagic" response. It is, however, well understood that if the supply of ammonia to liver metabolism is exceptionally high (e.g., hyperammoniation), then the animal will increase its intake of energy in an attempt to supply precursors to clear the "toxin." Finally, the study by Marotti (2004) also posed an interesting dilemma that might support the synchronization of VFA yield and ammonia clearance. When animals were offered a grassclover sequence compared to a clover-grass sequence, the ratio of rumen ammonia to propionate was higher in the former than the

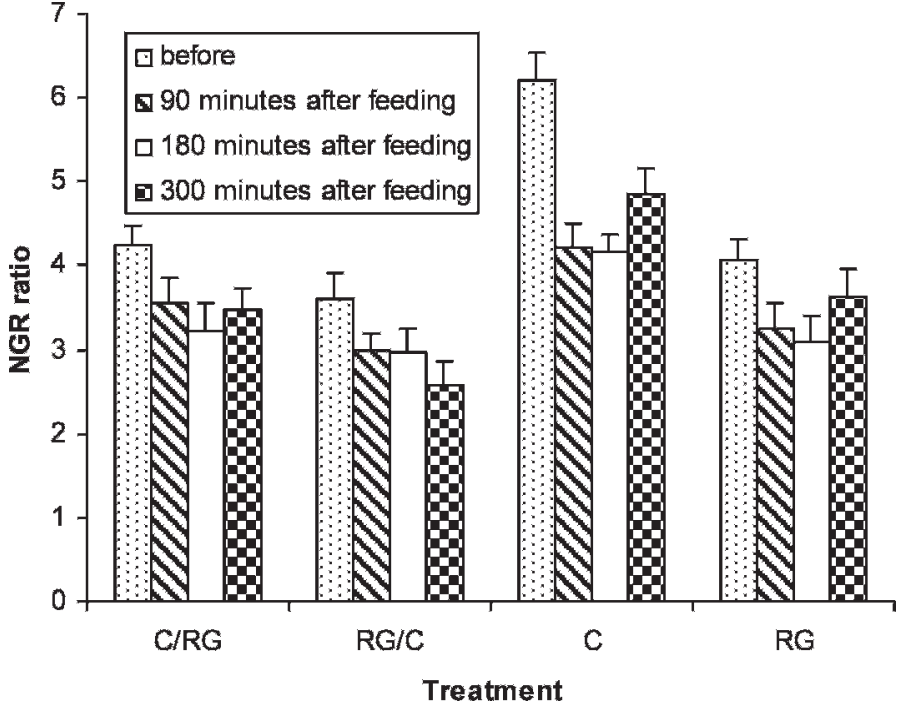

Figure 2. Ratio of nonglucogenic to glucogenic volatile fatty acids (NGR) of rumen fluid of animals adjusted to sole forage (RG indicates perennial ryegrass; WC, white clover) or mixed herbage diets (offered as a sequence of RG first and then WC or WC first and then RG; 90 min, $180 \mathrm{~min}$, and $300 \mathrm{~min}$ postprandial).

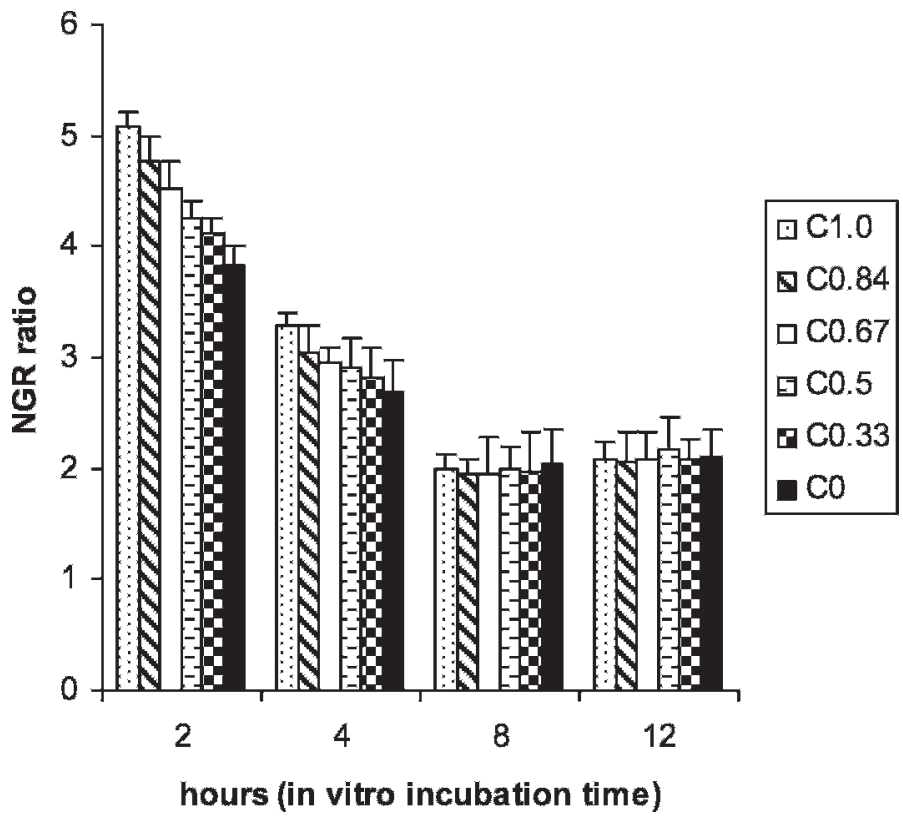

Figure 3. Ratio of nonglucogenic to glucogenic volatile fatty acids (NGR) of rumen fluid in vitro from sheep acclimatized to a ration containing $100 \%$ perennial rye grass challenged with various ratio of subterranean clover and perennial ryegrass. C1.0 indicates in vitro fermentation challenged with $100 \%$ subterranean clover; C0.84, in vitro fermentation challenged with $84 \%$ subterranean clover and 16\% perennial ryegrass (dry matter [DM] basis); C0.67, in vitro fermentation challenged with $67 \%$ subterranean clover and $33 \%$ perennial ryegrass (DM basis); C0.5, in vitro fermentation challenged with $50 \%$ subterranean clover and $50 \%$ perennial ryegrass (DM basis); $C 0.33$, in vitro fermentation challenged with 33\% subterranean clover and $67 \%$ perennial ryegrass (DM basis); and $\mathrm{C} 0$, in vitro fermentation challenged with $100 \%$ perennial ryegrass (DM basis). 
$(+)$

propionate

flux to liver

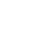
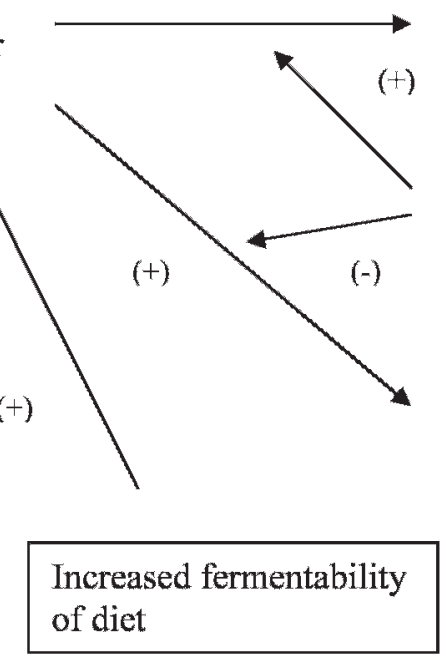

gluconeogenesis

$(+)$

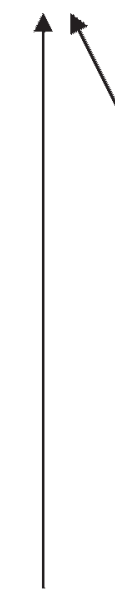

$(+)$

Increased glucose demand

oxidation

$(-)$

Feed intake

Figure 4. How propionate can affect satiety in ruminants (after Allen et al. 2005).

latter. This apparent synchronization supports the co-role of ammonia and propionate in the development of a hypophagic response. Furthermore, similar observations have been reported by Rutter (2006) in studies that examined the diurnal variation of partial preference in spatially separated pastures. In the studies presented by Rutter, sheep consistently switched from clover to grass late in the day, thus suggesting that the animal has certain degree of control in limiting ammonia and propionate build up and that there might well be an "optimal" ratio of ammonia to NGR (Chilibroste et al. 2007).

\section{IMPLICATIONS}

There is considerable evidence that when offered a free choice between different forage species presented in a pasture association, ruminants will choose a mixed diet, even when one dietary component could meet all of their nutritional needs. However, what is the nutritional basis of the dietary choices that ruminants make? We suggest that the most attractive theory proposed to induce satiety in grazing ruminants is based on 1) the rate of release of ammonia from the soluble protein fraction of the forage, and subsequent uptake in the blood, and 2) the apparent shift in nonglucogenic to glucogenic VFA production during fermentation. If these processes are considered in unison, the cessation of feeding and switching of diet is a hypophagic effect of propionate and, potentially, ammonia, yielded to portal circulation. These observations support the theories associated with synchronization of $\mathrm{C} / \mathrm{N}$ in the ration consumed by the animal. Furthermore, the observations that animals switch from clover to ryegrass late in the day could be explained by the animal maintaining a degree of control in limiting ammonia and propionate buildup, thus optimizing the ratio of ammonia to NGR in the rumen.

\section{POSTSCRIPT}

The question posed in the previous section, "what is the nutritional basis of the dietary choices that ruminants make?" has been partially answered by the unification of synchronization theory (tradeoff between loss and capture of $\mathrm{N}$ by rumen microflora and the supply of OM truly degraded in the rumen) and postabsorptive consequences of the synthesis of energy-yielding (propionate hypophagia) substrates. However, our proposal only provides a mechanism to understand the cessation of feeding and does not elaborate the processes involved, or ability of the animal to redress the nutritional imbalances. Does the lactating ruminant demonstrate complementary food selection as a mechanism to redress nutrient imbalances? Briefly, theories associated with complementary feeding as a functional process to redress short-term and, potentially, long-term nutrient imbalances have been demonstrated in a range of organisms. Complementary food selection (food mixing) can be proposed as beneficial to the grazing ruminant for three main reasons: 1) mixing using a range of substitutable food types reduces the animal's reliance on any one, thus reducing the likelihood that any one food in the environment would be depleted; 2) mixing might be beneficial in enabling the animal to ingest an array of feeds containing subacute concentrations of toxins rather than ingesting an acute dose from one feed type; or 3) mixing can lead to improvements in the overall nutritional quality of the diet, allowing the animals to regulate the balance of nutrients that they ingest. It is the latter that might be important in the redress of nutrient imbalances over the long term. There is very little experimental evidence published to support the paradigm that complementary feeding is a tenable strategy to redress long-term nutritional imbalance in lactating ruminants. However, the lactating dairy cow might be an ideal mammalian model to demonstrate complementary food selection as the overall energy and $\mathrm{N}$ intakes of the animal marginally fulfil the long-term requirements of the animal, thus leading to the suggestion that it does not have a robust nutritional strategy to cope with nutritional imbalances. As a consequence, rather than maintain the energy or $\mathrm{N}$ output under conditions of nutritional stress, the lactating cow reduces her energy and $\mathrm{N}$ expenditure while maintaining her intake of nutrients.

\section{LITERATURE CITED}

Allen, M. S., B. J. Bradford, and K. J. Harvatine. 2005. The cow as a model to study food intake regulation. Annual Reviews of Nutrition 25:523-547.

Baile, C. A., and C. I. McLaughlin. 1987. Mechanisms controlling feed intake in ruminants: a review. Journal of Animal Science 64:915-922.

BALAz, S. 2000. Lipophilicity in trans-bilayer transport and subcellular pharmokinetics. Perspectives in Drug Discovery and Design 19:157-177.

Baldwin, R. L., J. H. M. Thornley, and D. E. Beever. 1987. Metabolism of the lactating dairy cow: II. Digestive elements of a mechanistic model. Journal of Diary Science 54:107-131.

Bannink, A., J. DiJkstra, S. J. Koopmans, and Z. Mroz. 2006. Physiology, regulation and multifunctional activity of the gut wall: a rationale for multicompartmental modeling. Nutrition Research Reviews 19:227-253.

Bannink, A., J. France, S. Lopez, W. J. J. Gerrits, E. Kebreab, S. Tamminga, and J. DIJKSTRA. 2007. Modelling the implications of feeding strategy on rumen 
fermentation and functioning of the rumen wall. Animal Feed Science and Technology 143:3-26.

Berminham, E. N., P. Noziere, J. Vernet, H. Lapierre, S. Leger, D. Sauvant, and I. ORTIGUes-Marty. 2007. The relationships between intake and net portal fluxes of energy metabolites in ruminants: a meta-analysis. Animal Feed Science and Technology 143:27-58.

Blümmel, M., A. Karsli, and J. R. Russell. 2001. Influence of diet on growth yields of rumen micro-organisms in vitro and in vivo: influence on growth yield of variable carbon fluxes to fermentation products. British Journal of Nutrition 90:625-634.

Chapman, D. F., A. J. Parsons, G. P. Cosgrove, D. J. Barker, D. M. Marotti, K. J. Venning, S. M. Rutter, J. Hill, and A. N. Thompson. 2007a. Impacts of spatial patterns in pasture on animal grazing behaviour, intake and performance. Crop Science 47:399-415.

Chapman, D. F., A. J. Parsons, J. Hill, and K. Venning. 2007b. Forage factors and dietary choice. Journal of Animal Science 85(Suppl. 1):386-387.

Chilibroste, P., J. Dijkstra, and S. Tamminga. 2001. Design and evaluation of a non steady state rumen model. Netherlands Journal of Agricultural Science 49:297-312.

Chilibroste, P., P. Soca, D. A. Mattiauda, O. Bentancur, and P. H. Robinson. 2007. Short term fasting as a tool to design effective grazing strategies for lactating cattle: a review. Australian Journal of Experimental Agriculture 47:10751084.

Conrad, R., C. Balle, and J. Mayer. 1977. Changing meal patterns and suppression of feed intake with increasing amounts of dietary non protein nitrogen in ruminants. Journal of Dairy Science 60:1725-1733.

Cosgrove, G. P., C. B. Anderson, A. J. Parsons, J. L. Brock, and J. C. Tilbrook. 2002. Can nitrogen-fertilised ryegrass substitute for white clover? Proceedings of the New Zealand Grassland Association 64:205-209.

Dewhurst, R. J., D. R. Davies, and R. J. MerRy. 2000. Microbial protein supply from the rumen. Animal Feed Science and Technology 85:1-21.

Dijkstra, J., H. Boer, J. Van Bruchem, M. Bruining, and S. Tamminga. 1993. Absorption of volatile fatty acids from the rumen of lactating dairy cows as influenced by volatile fatty acid concentration, $\mathrm{pH}$ and rumen liquid volume. British Journal of Nutrition 69:385-396.

Dijkstra, J., J. A. N. Mills, and J. France. 2002. The role of dynamic modeling in understanding the microbial contribution to rumen function. Nutrition Research Reviews 15:67-90.

Doyle, P. T., C. R. Stockdale, A. R. Lawson, and D. C. Cohen. 2000. Pastures for dairy production in Victoria. 2nd ed. Victoria, Australia: Department of Natural Resources and Environment, Kyabram. 89 p.

Dumont, B. 1997. Diet preferences of herbivores at pasture. Annales Zootechnique 46:105-116.

Egan, A. R. 1977. Nutritional status and intake regulation in sheep. VIII. Relationships between voluntary intake of herbage by sheep and the protein/ energy ratio in the digestion products. Australian Journal of Agricultural Research 28:907-914

Enemark, J. M., R. J. Jorgensen, and P. St. Enemark. 2002. Rumen acidosis with special emphasis on diagnostic aspects of subclinical rumen acidosis: a review. Veterinarija ir Zootechnika 20:16-29.

ForBes, J. M. 1995. Voluntary food intake and diet selection. Oxford, United Kingdom: CAB International. $407 \mathrm{p}$.

FrYXELL, J. M. 1991. Forage quality and aggregation by large herbivores. American Naturalist 138:478-498.

Hodgson, J., AND I. M. Brookes. 1999. Nutrition of grazing animals. In: J. White and J. Hodgson [EDS.]. New Zealand pasture and crop science. Auckland, New Zealand: Oxford University Press. p. 117-132.

IluIus, A. W., AND N. S. Jessop. 1996. Metabolic constraints on voluntary intake in ruminants. Journal of Animal Science 74:3052-3062.

Kaswari, T., P. Lebzien, G. Flachowsky, and U. ter Meulen. 2007. Studies on the relationship between the synchronization index and the microbial protein synthesis in the rumen of dairy cows. Animal Feed Science and Technology 139:1-22

Kertz, A. F., M. K. Koepke, L. E. Davidson, N. L. Betz, J. R. Norris, L. V. Skoch, B. R. CoRds, AND D. T. HopkINs. 1982. Factors influencing intake of high urea- containing rations by lactating dairy cows. Journal of Dairy Science 65:587-604.

Ketelaars, J. J. M. H., and B. J. Tolkamp. 1992a. Toward a new theory of feed intake regulation in ruminants. 1. Causes of difference in voluntary feed intakecritique of current views. Livestock Production Science 30:269-296.

Ketelaars, J. J. M. H., and B. J. Tolkamp. 1992b. Toward a new theory of feed intake regulation in ruminants. 3 . Optimum feed intake in search of a physiological background. Livestock Production Science 31:235-258.

Kim, K. H., J. J. Choung, and D. G. Chamberlain. 1999. Effects of varying the degree of synchrony of energy and nitrogen release in the rumen on the synthesis of microbial protein in lactating dairy cows consuming a diet of grass silage and a cereal-based concentrate. Journal of the Science of Food and Agriculture 79:1441-1447.

KNIGHT, C. H. 2001. Lactation and gestation in dairy cows: flexibility avoids nutritional extremes. Proceedings of the Nutrition Society 50:527-537.

Kolver, E. S., L. D. Muller, G. A. Varga, and T. J. Cassidy. 1998. Synchronisation of ruminal degradation of supplemental carbohydrate with pasture nitrogen in lactating dairy cows. Journal of Dairy Science 81:2017-2028.

KRISTENSEN, N. B., AND D. L. HaRMon. 2004. Splanchnic metabolism of volatile fatty acids absorbed from the washed reticulorumen of steers. Journal of Animal Science 82:2033-2042.

LeNG, R. A. 1990. Factors affecting the utilisation of "poor quality" forages by ruminants, particularly under tropical conditions. Nutrition Research Reviews 3:277-294.

Lescoat, P., and D. Sauvant. 1995. Development of a mechanistic model for rumen digestion validated using duodenal flow of amino acids. Reproduction, Nutrition and Development 35:45-70.

Lopez, S., F. D. D. Hovell, J. Dijkstra, and J. France. 2003. Effects of volatile fatty acids on their absorption and on water kinetics in the rumen of sheep sustained by intragastric infusions. Journal of Animal Science 81:2609-2616.

Marotti, D. M. 2004. Behavioural limitations to pasture intake of ruminants [dissertation]. Parkville, Victoria, Australia: University of Melbourne. $227 \mathrm{p}$.

Mayne, C. S., AND I. A. WRIGHT. 1988. Herbage intake and utilization by the grazing dairy cow. In: P. C. Garnsworthy [ED.]. Nutrition and lactation of the dairy cow. Notttingham, United Kingdom: Butterworth. p. 280-294.

NewBold, J. R., AND S. R. Rust. 1992. Effect of asynchronous nitrogen and energy supply on growth of ruminal bacteria in batch culture. Journal of Animal Science 70:538-546.

Parsons, A. J., J. H. M. Thornley, J. A. Newman, and P. D. Penning. 1994. A mechanistic model of some physical determinants of intake rate and diet selection in a twospecies temperate grassland sward. Functional Ecology 8:187-204.

Penning, P. D., A. J. Rook, and R. J. OrR. 1991. Patterns of ingestive behaviour of sheep continuously stocked on monocultures of ryegrass or white clover. Applied Animal Behaviour Science 31:237-250.

Pfister, J. A., F. D. Provenza, G. D. Manners, D. R. Gardner, and M. H. Ralphs. 1997. Tall larkspur ingestion: can cattle regulate intake below toxic levels? Journal of Chemical Ecology 23:759-777.

Provenza, F. D. 1995. Postingestive feedback as an elementary determinant of food preference and intake in ruminants. Journal of Range Management 45:36-45.

ProvenzA, F. D. 1996. Acquired aversions as the basis for varied diets of ruminants grazing on rangelands. Journal of Animal Science 74:2010-2020.

Provenza, F. D., J. J. Villaba, J. Haskell, J. W. MacAdam, T. C. Griggs, and R. D. Wiedmeier. 2007. The value of plant physical and chemical diversity in time and space for herbivores. Crop Science 47:382-398.

Richardion, J. M., R. G. Wilkinson, and L. A. Sinclair. 2003. Synchrony of nutrient supply to the rumen and dietary energy source and their effects on the growth and metabolism of lambs. Journal of Animal Science 81:1332-1347.

RutTeR, S. M. 2006. Diet preference for grass and legumes in free-ranging domestic sheep: current theory and future application. Applied Animal Behaviour Science 97:17-35.

Rutter, S. M., K. L. Young, J. E. Cook, and R. A. Champion. 2003. Strip grazing separate white clover and ryegrass monocultures increases daily intake and milk yield in dairy cows. Tropical and Subtropical Agroecosystems 3:461-465.

Scaife, J. R., and J. Z. Tichivangana. 1980. Short chain acyl CoA synthetases in ovine rumen epithelium. Biochemika Biophysika Acta 619:445-450. 
Shabl, Z., A. Arieli, I. Bruckental, Y. Aharoni, S. Zamwel, A. Bor, and H. Tagari. 1998. Effect of synchronization of the degradation of dietary crude protein and organic matter and feeding frequency on ruminal fermentation and flow of digesta in the abomasum of dairy cows. Journal of Dairy Science 81:1991-2000.

Sinclair, L. A., P. C. Garnsworthy, J. R. Newbold, and P. J. Buttery. 1993. Effects of synchronizing the rate of dietary energy and nitrogen release on rumen fermentation and microbial protein synthesis in sheep. Journal of Agricultural Science, Cambridge 120:251-263.

Sinclair, L. A., P. C. Garnsworthy, J. R. Newbold, and P. J. Buttery. 1995. Effects of synchronizing the rate of dietary energy and nitrogen release in diets of similar carbohydrate composition on rumen fermentation and microbial protein synthesis in sheep. Journal of Agricultural Science, Cambridge 124:463472.

Speakman, J. R., R. J. Stubbs, and J. G. Mercer. 2002. Does body mass play a role in the regulation of food intake? Proceedings of the Nutrition Society 61:473-487.
Standing Committee on Agriculture. 1990. Feeding standards for Australian livestock. Ruminants. Melbourne, Australia: CSIR0 Publishing. 245 p.

Tolkamp, B., R. J. Dewhurst, N. C. Friggens, I. Kyriazakis, R. F. Veerkamp, and J. D. OLDHAm. 1998b. Diet choice by dairy cows: 1. Selection for feed protein content during the first half of lactation. Journal of Dairy Science 81:2657-2669.

Tolkamp, B., I. Kyriazakis, J. D. Oldham, M. Lewis, R. J. Dewhurst, and J. R. NewBold. 1998a. Diet choice by dairy cows: 2. Selection for metabolisable protein or for ruminally degradable protein. Journal of Dairy Science 81: 2670-2680.

Villalba, J. J., and F. D. Provenza. 1997. Preference for flavoured foods by lambs conditioned with intraruminal administration of nitrogen. British Journal of Nutrition 78:545-561.

Yearsley, J., B. J. Tolkamp, and A. W. Illius. 2001. Theoretical developments in the study and prediction of food intake. Proceedings of the Nutrition Society 60:145-156. 